\title{
Remazol reactive dye degrading Bacteria from freshwater fish of River Cauvery, Pallipalayam of Namakkal District, South India
}

\author{
A. Sankaranarayanan ${ }^{1,2^{*}} \mathbb{D}$, S. Karthikeyan ${ }^{1}$, Anoop Markande ${ }^{3}$ and Abhishek Sharma ${ }^{2}$
}

\begin{abstract}
Background: Azo dye effluents cause severe pollution problems in soil and water and affect their flora and fauna throughout the world. The combination of dye degrading bacteria in the gut of freshwater fish has been considered a prospective approach towards the development of a sustainable environment. In the southernmost part of India, especially in the Namakkal District of Tamil Nadu state, urbanization and industrial development lead to various environmental issues. In lieu, most of the earlier works were carried out on the bacterial dye degradation from soil and water sources, least concentration on the dye degradation from fish gut flora. The objective of this study was to analyze the role of dye degrading bacteria in the gut of freshwater fish collected from the study area.

Results: We have studied the aerobic degradation of remazol yellow reactive dye by bacteria forming the gut flora of exotic fish Oreochromis mossambica from river Cauvery at Pallipalayam of Namakkal District, India. Eight dye degrading gut isolates viz. Pseudomonas sp. AD1, Bacillus sp. AD2, Staphylococcus sp. AD3, Staphylococcus AD4, Enterobacter sp. AD5, Escherichia coli AD6, Streptococcus sp. AD7 and Clostridium sp. AD8 were obtained capable of growing in azo dye incorporated in Basic mineral medium (BMM) medium. Optimization study was carried out for various parameters for the selected isolates. Based on the growth, maximum growth was seen in Pseudomonas sp. AD1 (in 0-24 h) and minimum in Escherichia coli.AD 6 (in 72-96 h). Pseudomonas sp. AD1, Enterobacter sp.AD5, and Bacillus sp. AD 2 exhibited efficient dye degradation during $0-96 \mathrm{~h}$ analysis which was confirmed by FTIR analysis. Loss of azo group stretch at $1572-76 \mathrm{~cm}^{-1}$ and $1429 \mathrm{~cm}^{-1}$ and presence of primary (-NH2-) and secondary amides (-NH2-), aliphatic $-\mathrm{C}-\mathrm{N}-$ stretching and confirmed -C-S- stretching in FTIR analysis confirms the breaking down of the azo bond.
\end{abstract}

Conclusion: This study showed that there is a platform for using the bacterial flora of fish gut that paves a prominent way in the degradation of Azo dye.

Keywords: Azo dye, Remazol yellow, Oreochromis mossambica, Gut flora, Bacteria, FTIR analysis

\section{Background}

Environmental pollution has been considered as one of the serious problems throughout the World especially from the textile industries (Khan and Malik 2014). The known reasons behind this are industrialization, urbanization, and other man-made activities. Textile dyes have

\footnotetext{
${ }^{*}$ Correspondence: drsankarkamal@gmail.com

${ }^{1}$ Research Department of Microbiology, K. S. Rangasamy College of Arts

\& Science, Namakkal District, Tiruchengode, Tamil Nadu 637 215, India

Full list of author information is available at the end of the article
}

been used for many years for coloring and printing fabrics. The effluent contains recalcitrant and other hazardous contents, not only carcinogenic and toxic to humans and other biotic organisms (Mahmoud et al. 2010; Reddy Roja et al. 2020) especially the recalcitrant nature of azo dye and the various issues raised by the releasing of azo dye in aquatic systems (Sinha et al. 2019a, b; Lade et al. 2012) and various disorders to human health systems (Saratale et al. 2011; Chung and Cerniglia 1992) were reported already. The complex aromatic structure of textile dye resisted detergent, sunlight, and temperature 
a noteworthy point mentioned here. The effluent from dye-stuff industries has contaminated the soil as well as surface and underground water ( $\mathrm{Fu}$ and Vijayaraghavan 2001) and responsible for a lot of problems in an aquatic environment. The prominent uses of Azo dyes in diversified industries like textile, leather, printing, plastic, pharmaceutical, and food. The dyeing industries used water as a principal medium for the application of dyes, and discharge the wastewater, as one among the important medium for an aquatic pollutant (Sweety 2018). Different types of dyes and additives are known which make this an organic as well as inorganic pollutant source in textile effluent. With $80 \%$ of total azo dye consumption in dying industries, India is ranked second in the world (Juwarkar et al. 1997). In India, textile industries are contributing to about $25 \%$ of total export earnings and employing almost the total labor force (MSME report 2013). Pallipalayam, Namakkal District, Tamil Nadu state is one of the important business domains for textile and dye industries (Olukanni et al. 2005). Hence we need a vital bio-mediated alternate option for remediated the polluted site to maintain a sustainable environment.

Though numerous soil and water based potential dye degrading bacteria were existing in the environment, the present study dealt with the discharged water from dye industry mixed with the river water, hence the fish gut dwelling bacteria from the polluted river was taken into account. Besides, fishes are continuously exposed to the microorganisms present in water and sediment. The intestinal tract of fishes is populated which harbors a high load of microorganisms due to the availability of more organic matter consumed by fish as food. The organisms may enter the mouth with water or food and pass through and/or colonize the digestive tract. The economic constraints as a hurdle in the existing dye effluent treatment process viz. adsorption, filtration, coagulation, and chemical flocculation insisted the need for alternate eco friendly approaches through biotic organisms (Sanmuga Priya et al. 2015). In addition with this, the recently published report revealed the novel utility of bacteria from fish gut wastes are used for the detoxification of textile dye (Reddy Roja et al. 2020).

Azo dyes are known to undergo reductive cleavage whereas the resultant aromatic amines are metabolized under aerobic conditions (Sathian et al. 2013). So for complete mineralization of azo dyes, the microbial population forming part of the treatment system should be able to work efficiently to find an alternative to developing a sustainable environment. Because of these problems, the most potent bacterial culture was taken from the fish gut was taken into consideration for the present study. In the present work, degradation of an azo dye- Remazol yellow was studied using gut flora of exotic freshwater fish
Oreochromis mossambica and analyzed by Fourier transform infrared spectroscopy (FTIR).

\section{Materials and methods \\ Bacterial isolates}

O. mossambica fishes (20 nos.) (Barragan et al. 2007) were collected from river Cauvery at Vasantha Nagar of Pallipalayam of Namakkal district. The physico chemical parameters of water samples were measured and recorded at the site of fish collection. The foregut flora was eviscerated and contents were transferred aseptically into the nutrient broth and incubated overnight in a shaker for enrichment at $37^{\circ} \mathrm{C}$.

\section{Isolation of azo dye degrading bacteria}

After enrichment, the broth was spreaded on Basic mineral medium (BMM) [ $\mathrm{NaNO}_{3}(2.0 \mathrm{~g} / \mathrm{L}), \mathrm{NaCl}(0.8 \mathrm{~g} / \mathrm{L})$, $\mathrm{CaCl}_{2} \cdot 2 \mathrm{H}_{2} \mathrm{O}(0.1 \mathrm{~g} / \mathrm{L}), \mathrm{KH}_{2} \mathrm{PO}_{4}(2.0 \mathrm{~g} / \mathrm{L}), \mathrm{Na}_{2} \mathrm{HPO}_{4} \cdot 12 \mathrm{H}_{2} \mathrm{O}$ $(2.0 \mathrm{~g} / \mathrm{L}), \mathrm{MgSO}_{4}(0.2 \mathrm{~g} / \mathrm{L}), \mathrm{FeSO}_{4} .7 \mathrm{H}_{2} \mathrm{O}(0.001 \mathrm{~g} / \mathrm{L})$; Agar $18-20 \mathrm{~g} / \mathrm{L}]$ containing an azo dye-Remazol yellow (0.5 g) as the sole carbon source for a period of 4 days at $37{ }^{\circ} \mathrm{C}$ (Ajaz et al. 2019). Based on the growth of the organism, the predominant isolates were taken for spectrophotometric analysis. (Nachiyar and Rajkumar 2003; Pandey et al 2007). The optimal growth conditions of various parameters $(\mathrm{pH}$, temperature, concentration of dye, amount of bacteria and agitation speed) were determined as per standard procedure (Ajaz et al. 2019). Further the morphological parameters and and biochemical tests were performed for the predominant isolates as per standard procedure (Cappucino and Sherman 2008).

\section{Optimization of various parameters:}

Optimization of various parameters were carried out as per the standard procedure (Ajaz et al. 2019) ie. $\mathrm{pH}(5,6$ and 7), temperature $\left(30^{\circ} \mathrm{C}, 37^{\circ} \mathrm{C}\right.$ and $\left.45^{\circ} \mathrm{C}\right)$, agitation speed (125 rpm, $150 \mathrm{rpm}, 175 \mathrm{rpm}$ and $200 \mathrm{rpm}$ ) [for Clostridium sp. AD8 static condition was maintained] and amount of bacteria (2\%, 4\%, 6\%, $8 \%$ and $10 \%) .100 \mathrm{ml}$ of Basic mineral medium (BMM) was taken and inoculated with $2 \%$ bacterial suspension and incubated. Stock solution of dye was added into the BMM to obtain a final dye concentration of $50 \mathrm{mg} / \mathrm{L}$. Aliquot was taken at $0 \mathrm{~h}$ and after 4 days to measure the initial and final absorbance. Aliquot was centrifuged before measuring the optical density at $600 \mathrm{~nm}$. Decolourization percentage was calculated as per following formula.

$$
\begin{aligned}
& \text { Decolourization }(\%) \\
& =\frac{\text { Initial absorbance-Final absorbance }}{\text { Initial absorbance }} \times 100
\end{aligned}
$$


Dye decolorization assay by UV-Vis Spectrophotometer Bacterial inoculums were freshly prepared by incubating bacterial suspension $(6 \% \mathrm{v} / \mathrm{v})$ in BMM broth with $0.5 \mathrm{~g}$ dye in an incubator shaker at $175 \mathrm{RPM}$ for $20 \mathrm{~h}$ at $37{ }^{\circ} \mathrm{C}$ (Remi Model No. 1575). At defined intervals of 1st, 2nd, 3rd, and 4th day, the cultures were withdrawn, centrifuged at $10,000 \mathrm{~g}$ and $10{ }^{\circ} \mathrm{C}$ for $15 \mathrm{~min}$, and the supernatant was examined for absorbance at $600 \mathrm{~nm}$ under visible light range in a spectrophotometer (Perkins 1987) (Shimadzu-1800). Based on the results, the efficient organisms alone were taken for FTIR analysis. (Sanmuga Priya et al. 2016).

\section{Biodegradation of dye by Fourier transform infrared spectroscopy (FTIR) analysis}

For the characterization of functional groups, the dye was studied before and after decolourisation. The FTIR analysis was performed in the mid IRF region of 400$4000 / \mathrm{cm}$. The effluent retained after biodegradation of Remazol yellow dye with the isolates were extracted with equal volumes of ethyl acetate. Then, the extract was dried over anhydrous $\mathrm{Na}_{2} \mathrm{SO}_{4}$ and evaporated in a dry bath, and then dissolved in ethanol to use for FTIR analysis (Thermo Fisher) (Bisschops and Spanjers 2003; Phugare et al. 2011; Saratale et al 2009).

\section{Statistical analysis}

Statistical analyses were done by using Graph Pad PRISM version 6.01. For the analysis of the degradation ability of the isolates, colony statistics using one-sample t-test was employed.

\section{Result and discussion}

\section{Bacterial isolates}

The usage of different chemicals in the textile industry, a challenging task for the removal of dye from wastewater (Khan and Malik 2016; Moosvi et al. 2005). The pollutants from dye industry not only pollute the water, but they also pollute soil too (McMullan et al. 2001). In the present study, based on the biochemical tests and the growth on selective media, seven bacterial genera were obtained from the 76 isolates were isolated from the gut flora of exotic fish O. mossambica normally dwelling including polluted water bodies (Talwar and Jhingran 1991). The results are presented in Table 1. Biodegradation of xenobiotics involves an anaerobic, aerobic, or sequential combination of the two processes. Anaerobic degradation of azo dyes is known to yield only azo reduction and decolorisation (Melgoza et al. 2004). In general, complete mineralization of azo dyes requires both anaerobic and aerobic bacterial processes. The sequential anaerobic/aerobic treatment processes based on mixed culture of bacteria are widely used because the
Table 1 Bacterial genera isolated from the gut flora of 0 . mossambica

\begin{tabular}{lll}
\hline Name of the fish & No. of isolates obtained & $\begin{array}{l}\text { Name of the bacterial } \\
\text { isolates }\end{array}$ \\
\hline O. mossambica & 76 & Pseudomonas sp.,AD1 \\
& & Bacillus sp., AD2 \\
& Staphylococcus sp., AD3 \\
& Staphylococcus sp., AD4 \\
& Enterobacter sp., AD5 \\
& Escherichia coli AD6 \\
& Streptococcus sp., AD7 \\
& Clostridium sp., AD8 \\
\hline
\end{tabular}

degradation products that result from anaerobic reduction of azo dyes have to be degraded by aerobic processes (Husseiny 2008; Kodam et al. 2005). In addition with this, though a number of bacteria in soil and water showed potentiality in dye degradation, however in a recent study revealed the firewater fish gut bacterial flora involved in the degradation of malachite green ( Reddy Roja et al. 2020), further the bacteria residing in fish gut may played a potential role in dye degradation than the water and sediment sources.

\section{Isolation of azo dye degrading bacteria}

The isolates ie. Pseudomonas sp. AD1 Bacillus sp. AD2, Staphylococcus sp. AD3 \& AD4, Enterobacter sp. AD5, Escherichia coli AD6, Streptococcus sp. AD7 and Clostridium sp. AD8 were selected and grown in BMM with dye. Azo dyes are the most widely used and account for over $60 \%$ of the total number of dyes manufactured (Saratale et al. 2009; APHA 1992). The reduction of the azo bond by azo reductase under anaerobic conditions was already reported (Moutaouakkil, et al. 2003). However, there are certain oxygen insensitive or aerobic azo reductases that have been reported from aerobic microorganisms (Elisangela et al. 2009; Kalyani et al. 2008). In azo dyes, certain carboxylated analogs of sulfonated azo compounds are utilized aerobically as a sole source of carbon and energy by specifically adapted bacteria (Chivukula and Renganathan 1995), hence the present study was concentrated only on aerobic degradation of azo dye. Further Shah (2014) reported the degrading ability of dye was varied with different bacterial species. This finding was coincided with the current study findings were the maximum dye degradation was reported in Staphylococcus AD4 and it was confirmed by FTIR analysis.

\section{Optimization of various parameters}

Regarding the optimization of various parameters, the results revealed that the maximum decolourization at 
$\mathrm{pH} \mathrm{7,} \mathrm{temperature} 37^{\circ} \mathrm{C}$, agitation speed $175 \mathrm{rpm}$ and amount of bacterium $6 \%$ were obtained (Fig. 1a-d). The optimization values of various parameters were determined by measuring the optical density at $600 \mathrm{~nm}$. The present study findings were supported by various earlier studies. Ajaz et al (2019) reported the synazol red degradation by Alcaligens aquatilis at $\mathrm{pH} 7$, temperature $37{ }^{\circ} \mathrm{C}$ with agitation speed $200 \mathrm{rpm}$. In another study, the optimal conditions for B. cereus and B. megatarium were found to be $37^{\circ} \mathrm{C}, \mathrm{pH} 7$ and $8 \%$ of inoculums by the degradation of an azo dye (Shah et al. 2013). Further there was a study insisted the need of strong coordination between physico-chemical and microbiological parameters in the degradation of dye (Shah 2014).

\section{Dye decolorization assay by UV-Vis Spectrophotometer}

The dye decolorization efficiency of individual species was determined by UV-Vis spectrophotometric analysis at $600 \mathrm{~nm}$ for 0-96 h. The results were presented in Fig. 2. Staphylococcus sp. AD4 and Streptococcus sp. AD7 exhibited high absorbance at $24 \mathrm{~h}$ while it was reduced significantly $(\mathrm{p}<0.05)$ after the determined incubation time of 96 h. Only Bacillus sp. AD2 reduced the dye absorbance significantly $(\mathrm{p}<0.01)$ to near zero after the incubation period. In Pseudomonas sp. AD1 and Staphylococcus sp. $\mathrm{AD} 3$, the absorbance seems to be increasing owing to the production of pigments by the isolates in the medium. Enterobacter sp. AD5 and Escherichia sp. AD6 exhibited a non-significant reduction of absorbance. Pseudomonas sp. exhibited about $90 \%$ and $86 \%$ decolorization at 100 and $200 \mathrm{mg} / \mathrm{l}$ concentration and above this concentration decrease in degradation in Mordant black dye. Pseudomonas sp. is the microorganism that shows the highest activity on dyes selected. Pseudomonads are reported to grow considerably on plates since $96 \mathrm{~h}$ of incubation using different classes and chemical subclasses of textile
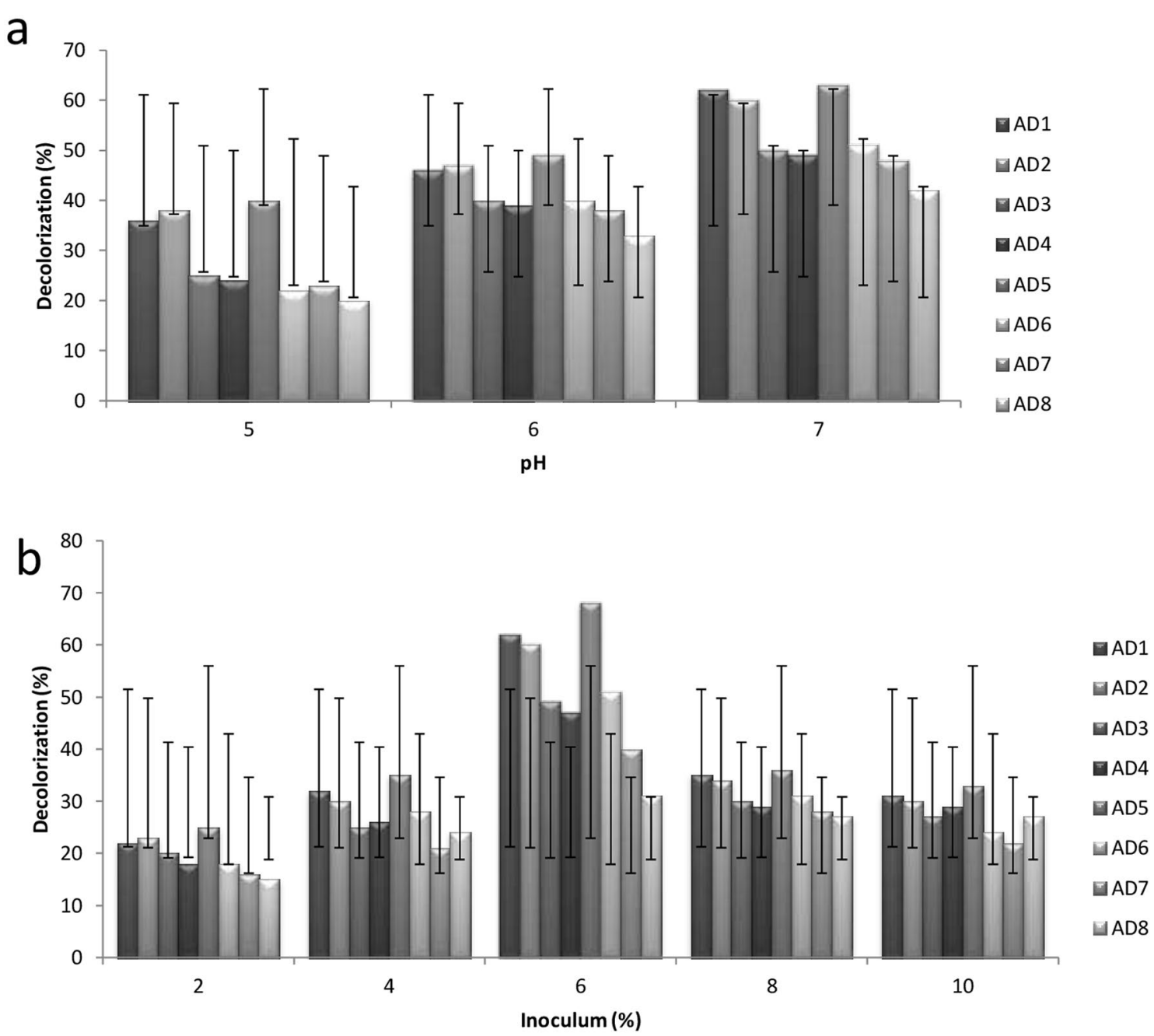

Fig. 1 Optimization studies for various parameters a pH b Inoculum c Temperature d Agitation speed 

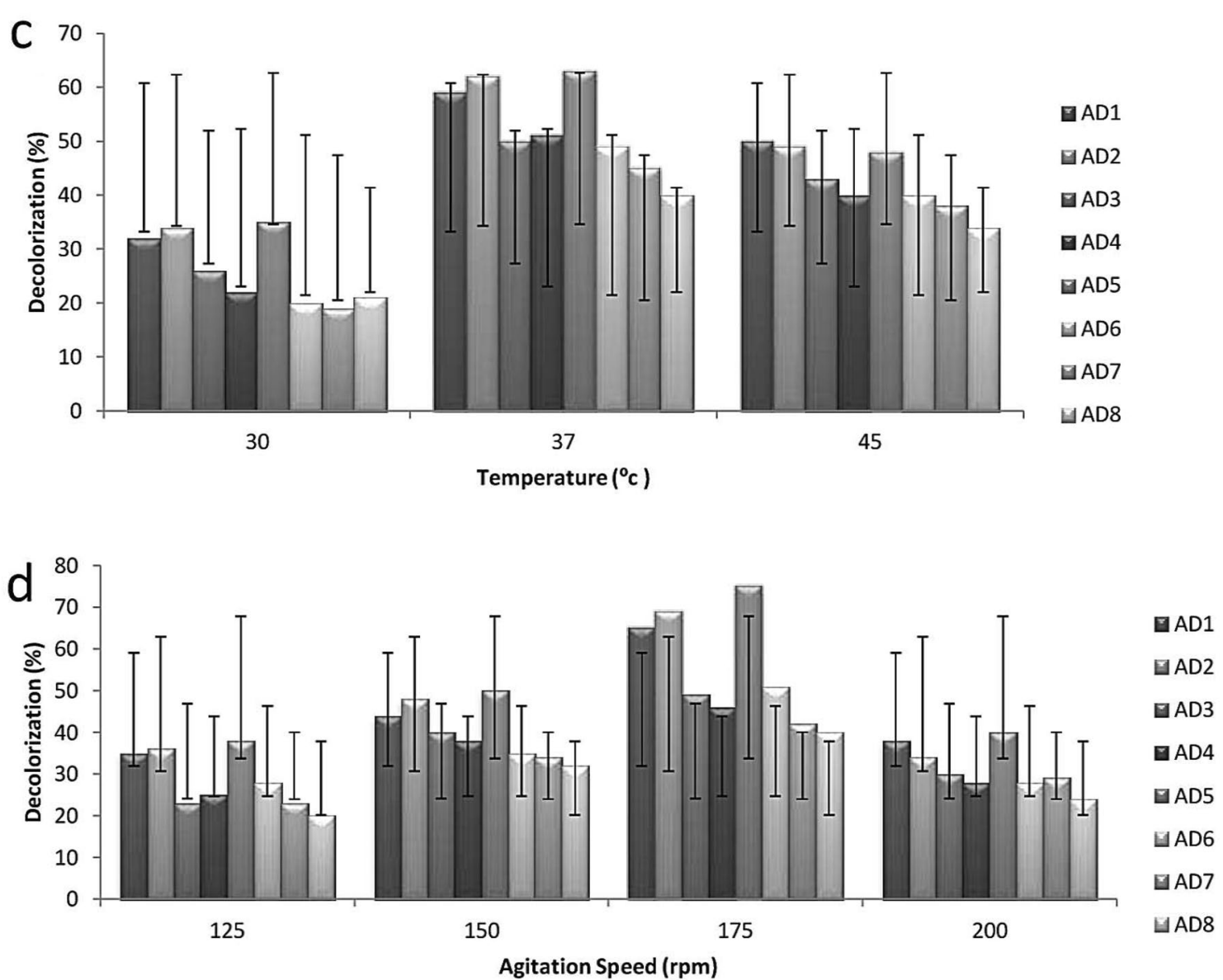

Fig. 1 continued

dyes, including azo, nitro, tri-phenyl methane, and anthraquinone types as the only source of carbon (BMM, dye, and agar) (Afreen et al. 2017). Earlier reports strongly revealed that the role of Pseudomonas sp. in decolorization and degradation (Moosvi et al. 2005). In the present study, findings were also supported the Pseudomonas sp. role in the decolorization of Remazol dye than the other organisms were isolated from the study area. Based on the results, the efficient dye decolorization organisms such as Pseudomonas sp. AD1, Bacillus sp. AD2 and Enterobacter sp. AD5, were taken for FTIR analysis. The results revealed that the decolorization was less in individual and consortium under aerobic conditions. This view was strongly supported by Moosvi et al. (2005) and only $12-22 \%$ performance was achieved within $48 \mathrm{~h}$. On the other hand, individual cultures Pseudomonas sp. were able to completely decolorize the azo dyes. Although Enterobacter sp., and Streptococcus sp., do not show similar activity which the Pseudomonas sp. does, this is the first time in which growth on textile dyes of these microorganisms is reported (Perkins 1987). The chemical structural differences in textile dyes due to the substitution of various functional groups on the aromatic base greatly influence their decolorization rates (Pasti-Grigsby et al. 1992; Dhanve et al. 2009). These views were supported in the present study. Pseudomonas sp, Streptococcus sp, and Staphylococcus showed variations in the degradation of Remazol dye.

\section{FTIR analysis}

Fourier Transform Infrared Spectroscopy (FTIR) analyses were done for the control and the decolorized sample (Fig. 3) and from the chromatogram, the results showed various peaks. At $1496 \mathrm{~cm}^{-1}$, aliphatic and at $1084 \mathrm{~cm}^{-1}$, aromatic stretching were exhibited. The presence of C-S stretching has been seen at $650-675 \mathrm{~cm}^{-1}$ confirms the denaturation of the sulfur bonds in the Ramazol Yellow structure. At 1161 and $1358 \mathrm{~cm}^{-1}$, symmetric and asymmetric SO2 stretching were seen respectively. Primary amide (-NH2-) bending was seen at $1630-37 \mathrm{~cm}^{-1}$. Secondary amide $(\mathrm{N}-\mathrm{H})$ stretching and wagging $(650-675$ and $3280-85 \mathrm{~cm}^{-1}$ ), and secondary amines were evident 


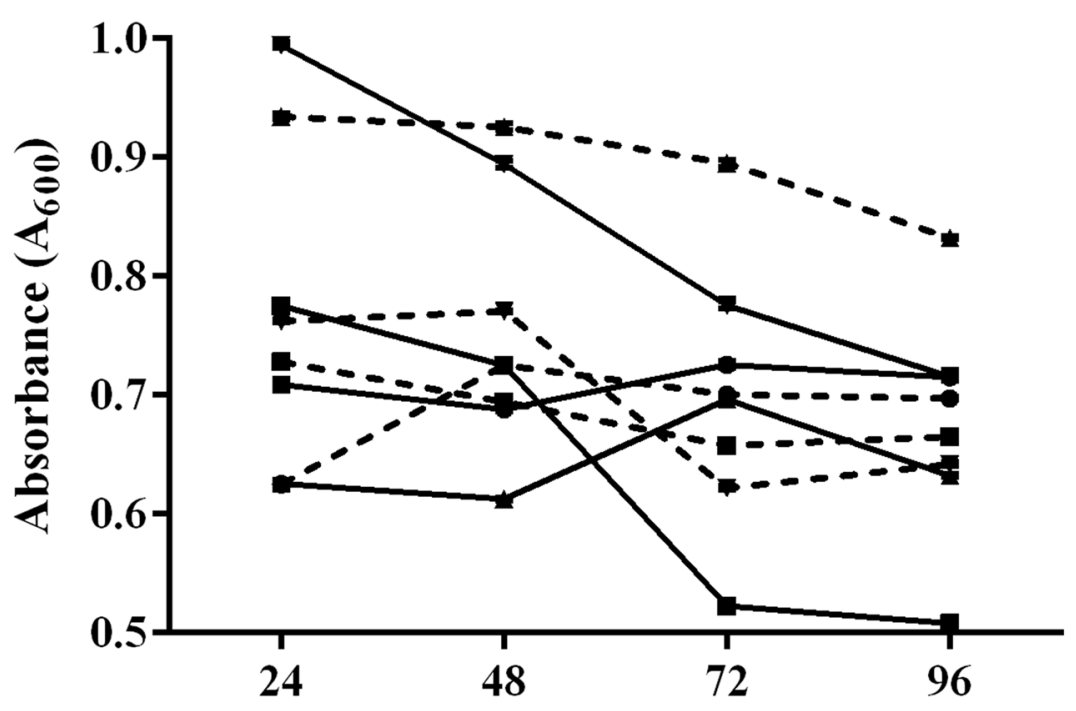

Time (h)

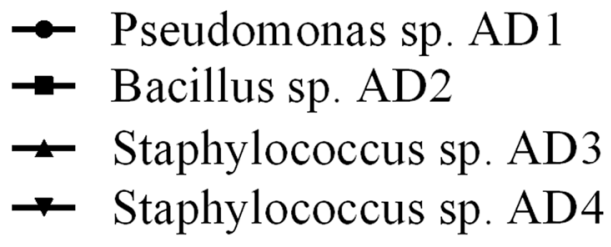

-•. Enterobacter sp. AD5

-2. Escherichia coli AD6

-r. Streptococcus sp. AD7

-r. Clostridium sp. AD8

Fig. 2 Dye decolourization assay using selective bacterial isolates by UV-Vis Spectrophotometer

at $1545-1550 \mathrm{~cm}^{-1}$. At $781 \mathrm{~cm}^{-1},-\mathrm{NH} 2$ wagging and twisting were seen. Aromatic/aliphatic isonitrile ($\mathrm{N} \equiv \mathrm{C}-$ ) stretching or possible azide stretching was seen at $2119-25 \mathrm{~cm}^{-1}$. Aromatic /aliphatic nitro compound (NO2) asymmetric stretching was seen at 1358, 1545$50 \mathrm{~cm}^{-1}$ and $1630-37 \mathrm{~cm}^{-1}$. Aliphatic $\mathrm{C}-\mathrm{N}$ stretching was seen at 1074 and $1161 \mathrm{~cm}^{-1}$ and aromatic $\mathrm{C}-\mathrm{N}$ stretching was seen at $1358 \mathrm{~cm}^{-1}$. The Oxime stretching $(\mathrm{C}=\mathrm{N}-\mathrm{OH})$ was seen at $1630-37 \mathrm{~cm}^{-1}$. In comparison to the control FTIR, the peaks observed in presence of strains tested exhibited new peaks. This may be due to azoreductase enzyme activity. In the earlier reports, azoreductase activity has been studied in detail after the remediation of azo dye by Enterobacter sp. (Prasad and Aikat 2014) and by Pseudomonas sp. (Zimmermann et al. 1982).

Spectrophotometric analysis data reveals the presence of aromatic amines in all the four azo dyes decolorized broths under microaerophilic conditions. FTIR results were analyzed according to published reports (Stuart 2004; Cheng and Cerniglia 1992). The formation of colorless aromatic amines in microaerophilic conditions can be a result of reductive cleavage of the azo bond $(-\mathrm{N}=\mathrm{N})$. Although the azo group $(-\mathrm{N}=\mathrm{N}-)$ specific stretch at $1400-1450 \mathrm{~cm}^{-1}$ was not observed. The stretching and wagging of secondary amides ($\mathrm{NH} 2-)$; bending of primary amide $(-\mathrm{NH} 2-)$, aliphatic $(-\mathrm{C}-\mathrm{N}-)$ stretching, and $-\mathrm{C}-\mathrm{S}$ - stretching were seen in all the four FTIR readings. Aromatic/aliphatic isonitrile $(-\mathrm{N} \equiv \mathrm{C}-)$ stretching or possible azide stretching was seen only in Clostridium sp.AD1, Enterobacter sp.AD5, Bacillus sp.AD2 while Pseudomonas sp. AD1 exhibited anhydride $(-\mathrm{C}=\mathrm{O})$ stretching. The FTIR results exhibited that the azo group was degraded by all the isolates analyzed and S- and $\mathrm{N}$ - groups were found to be still present in the system after the degradation of Remazol yellow dye.

On contrary, the aerobic process doesn't show the formation of aromatic amines, but very little quantity of degradation was observed within the same time. This suggests the inability of bacterial consortium for aerobic degradation of selected azo dyes. The general approach of biodegradation is to mineralize the textile dyes using the natural capability of native microorganisms. But, most of the textile azo dyes are xenobiotics, and its biodegradation results in the formation of 


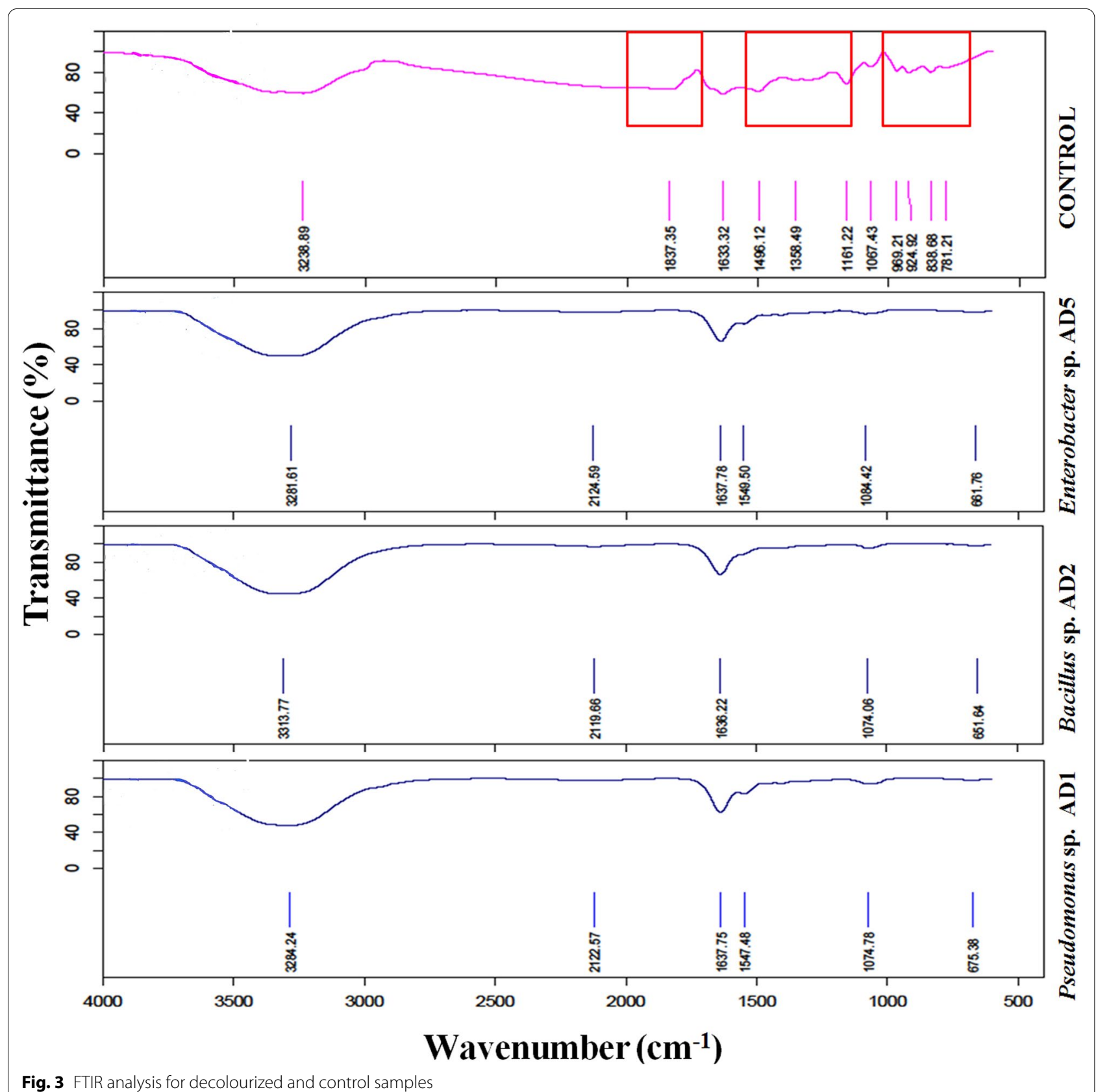

aromatic amines, which are more toxic than parent dyes and even carcinogenic or mutagenic (Levine 1991).

\section{Conclusions}

Pseudomonas sp. AD1 and Enterobacter sp. AD4 and Bacillus sp. AD2 are the most prominent bio decolourizing agents than the other isolated gut flora collected from exotic fish O. mossambica. The efficient degradation of dye by the above said organisms were confirmed by FTIR analysis within $96 \mathrm{~h}$ with the prominent loss of azo bonds seen in FTIR analysis. The present study gave a platform to further the approaches about the purification and quantification of the enzymes involved in the degradation by $S$ Pseudomonas sp. AD1 and Enterobacter sp. AD4 and Bacillus sp. AD2 isolates.

\section{Acknowledgements}

The authors are thankful to the Management of KS Rangasamy College of Arts and Science for providing the basic necessary facilities to carry out the work. 


\section{Authors' contributions}

ASN made a substantial contribution in designing the work and concept development. SK has carried out the field study and acquisition of data. AM interpreted the results and helped in statistical analysis. ASN and AS reviewed, edited, and shaped the manuscript. All authors are read and approved the final draft of the manuscript.

\section{Funding}

No external funding to carry out this work.

\section{Availability of data and materials}

The data used in the present study are available from the corresponding author based on reasonable request.

\section{Declarations}

Ethics approval and consent to participate

Not applicable.

\section{Consent for publication}

Not applicable.

\section{Competing interests}

No conflict of interests reported by the authors.

\section{Author details}

${ }^{1}$ Research Department of Microbiology, K. S. Rangasamy College of Arts \& Science, Namakkal District, Tiruchengode, Tamil Nadu 637 215, India. ${ }^{2}$ C.G. Bhaktha Institute of Biotechnology, Uka Tarsadia University, Gopal Vidhya Nagar, Surat District, Bardoli, Gujarat 394 35, India. ${ }^{3}$ P.D. Patel Institute of Applied Sciences, Charotar University of Science and Technology, Changa, Gujarat 388 421 , India.

Received: 22 December 2020 Accepted: 4 May 2021

Published online: 10 May 2021

\section{References}

Afreen S, Bano F, Ahmad N, Fatma T (2017) Screening and optimization of laccase from cyanobacteria with its potential in decolorization of anthraquinonic dye Remazol Brilliant Blue R. Biocatal Agric Biotechnol. https://doi.org/10.1016/j.bcab.2017.05.004

Ajaz M, Rehman A, Khan Z, Nisar MA, Hussain S (2019) Degradation of azo dyes by Alcaligenes aquatilis $3 \mathrm{c}$ and its potential use in the wastewater treatment. AMB Expr 9:64. https://doi.org/10.1186/s13568-019-0788-3

APHA (1992) Standard Method for the examination of Water and Wastewater, 18th edn. DC, USA, Washington

Barragan BE, Costa C, Marquez MC (2007) Bio-degradation of azo dyes by bacterial inoculated on solid media. Dyes Pigm 75:73-81

Bisschops I, Spanjers H (2003) Literature review on textile wastewater characterization. Environ Technol 24:1399-1411

Cappuccino JG, Sherman N (2008) Microbiology: A laboratory manual, vol 9. Pearson / Benjamin Cummings, Boston

Chivukula M, Renganathan V (1995) Phenolic azo dye oxidation by laccase from Pyricularia oryzae. Appl Environ Microbiol 61:4374-4377

Chung T, Cerniglia CE (1992) Mutagenicity of azo dyes: structure-activity relationships. Mutat Resist 277:201-220

Dhanve RS, Kalyani DC, Phugare SS, Jadhav JP (2009) Coordinate action of exiguobacterial oxido reductive enzymes in biodegradation of reactive yellow 84A dye. Biodegradation 20(2):245-255

Elisangela F, Andrea Z, Dias GF, Cristiano R, Durrant R, Artur CP (2009) Biodegradation of textile azo dye by a facultative Staphylococcus arlettae $\mathrm{VN}-11$ using a sequential microaerophilic/aerobic process. Int Biodeterior Biodegrad 63:280-288

Fu Y, Viraraghavan T (2001) Fungal decolorization of dye wastewaters: a review. Bioresour Technol 79:251-262

Husseiny SM (2008) Biodegradation of the reactive and direct dyes using Egyptian isolates. J Appl Sci Res 4:599-606
Juwarkar A, Padole LM, Oke BH (1997) HRTS effluent treatment. Indian Textile J 1:14-18

Kalyani DC, Patil PS, Jadhav JP, Govindwar SP (2008) Bio-degradation of reactive textile dye red $\mathrm{BLI}$ by an isolated bacterium Pseudomonas sp. SUK1. Bioresour Technol 9:4635-4641

Khan S, Malik A (2014) Environmental and health effects of textile industry wastewater. In: Malik A, Grohmann E, Akhtar R (eds) Environmental deterioration and human health. Springer, Dordrecht

Khan S, Malik A (2016) Degradation of Reactive Black 5 dye by a newly isolated bacterium Pseudomonas entomophila BS1. Can J Microbiol 62:220-232

Kodam KM, Soojhawon I, Lokhande PD, Gawai KR (2005) Microbial decolorization of reactive azo dyes under aerobic conditions. World J Microbiol Biotechnol 21:367-370

Lade HS, Waghmode TR, Kadam AA, Govindwar SP (2012) Enhanced biodegradation and detoxification of disperse azo dye Rubine GFL and textile industry effluent by defined fungal-bacterial consortium. Int Biodeterior Biodegrad 31(72):94-107

LevineWG, (1991) Metabolism of azo dyes: implication for De-toxification and activation. Drug Metab Rev 23:253-309

Mahmoud MA, Kastner A, Yeboah J (2010) Antecedents, environmental moderators and consequences of market orientation: A study of pharmaceutical firms in Ghana. J Medical Mark. 10(3):231-244

McMullan G, Meehan C, Conneely A, Nirby N, Robinson T, Nigam P, Banat IM, Marchant R, Smyth WF (2001) Mini review: microbial decolorization and degradation of textile dyes. Appl Microbiol Biot 56:81-87

Melgoza MR, Cruz A, Buitron G (2004) Anaerobic/aerobic treatment of colorants present in textile effluent. Water Sci Technol 50:149-155

Moosvi S, Keharia H, Madamwar D (2005) Decolourization of textile dye Reactive Violet 5 by a newly isolated bacterial consortium RVM 11.1. World J Microbiol Biotechnol 21:667-672

Moutaouakkil A, Zeroual Y, Dzayri FZ, Talbi M, Lee K, Blaghen M (2003) Bacterial degradation of azo dye Methyl red by Entrobacter agglomerans. Ann Microbiol 53:161-169

MSME report (2013) Brief Industrial profile of Namakkal District. Micro, Small and Medium Enterprises Development Institute, Chennai

Nachiyar CV, Rajkumar GS (2003) Degradation of tannery and textile dye, Navitan Fast Blue S5R by Pseudomonas aeruginosa. World J Microbiol Biotechnol 19:609-614

Olukanni OD, Osuntoki AA, Gbenle GD (2005) Textile effluent bio-degradation potentials of textile effluent-adopted and non-adopted bacteria. Appl Environ Microbiol 1:837-844

Pandey A, Singh P, lyendar L (2007) Bacterial decolorization and degradation of azo dyes. Int Biodeterior Biodegradation 59(2):73-84

Pasti-Grigsby MB, Paszczynski A, Goszczynski S, Crawford DL, Crawford RL (1992) Influence of aromatic substitution patterns on azo dye degradability by Streptomyces spp and Phanerochaete chrysosporium. Appl Environ Microbiol 58:3605-3613

Perkins WD (1987) Fourier transform-infrared spectroscopy Part II. Advantages of FT-IR J Chem Ed 64:A269-A271

Phugare SS, Kalyani D, Surwase S, Jadhav J (2011) Ecofriendly degradation, decolorisation and detoxification of textile effluent by a developed bacterial consortium. Ecotoxicol Environ Saf 74:1288-1296

Prasad SS, Aikat K (2014) Study of bio-degradation and bio-decolourization of Azo dye by Enterobacter sp SXCR. Environ Technol. https://doi.org/10. 1080/09593330.2013.856957)

Reddy Roja C, Sumathi V, Sai Vinathi D, Hemalatha T, Reddy DC, Kalarani V (2020) Novel utility of Bacteria of fish gut wastes collected from Local markets for Detoxification of Textile dyes and Recycling of water for cultivation. In: Ghosh SK, Saha PD, Di Francesco M (eds) Recent trends in Waste water treatment and water resource management. Springer, Singapore

SanmugaPriya E, SenthamilSelvan P, Umayal AN (2015) Biodegradation studies on dye effluent and selective Remazol dyes by indigenous bacterial species through spectral characterization. Desal Water Treat 55:241-251

SanmugaPriya E, SenthamilSelvan P, Umayal AN (2016) Decolorization and biodegradation of remazol reactive dyes by Clostridium species. 3 Biotech. https://doi.org/10.1007/s13205-015-0335-0 
Saratale RG, Saratale GD, Chang JS, Govindwar SP (2009) Eco friendly degradation of sulphonated diazo dye Reactive Green 19A using Micrococcus glutamicus NCIM 2168. Bioresour Technol 100:3897-3905

Saratale RG, Saratale GD, Chang JS, Govindwar SP (2011) Bacterial decolorization and degradation of azo dyes: a review. J Taiwan Inst Chem Eng 42(1):138-157

Sathian S, Radha G, Shanmugapriya V, Rajasimman N, Karthikeyan C (2013) Optimization and kinetic studies on treatment of textile dye wastewater using Pleurotus floridanus. Appl Water Sci. 3:41-48

Shah M (2014) Effective treatment systems for azo dye degradation: a joint venture between physico-chemical and microbiological process. Int J Environ Bioremed Biodegrad 2(5):231-242

Shah MP, Patel KA, Nair SS, Darji AM (2013) Potential effect of two Bacillus sp on decolorization of azo dye. J. Bioremed. Biodegrad 4:199

Sinha A, Lulu S, Vino S, Banerjee S, Acharjee OWJ (2019a) Degradaiton of reac tive green dye and textile effluent by Candida sp VITJASS isolated from wetland paddy rhizosphere soil. J Environ Chem Eng. 6(4):5150-5159

Sinha A, Lulu S, Vino S, Osborne WJ (2019b) Reactive green dye remediation by Alternanthera philoxeroides in association with plant growth promoting
Klebsiella sp. VITAJ23: A pot culture study. Microbiol Res 220:42-52. https://doi.org/10.1016/j.micres.2018.12.004

Stuart B (2004) Infrared spectroscopy: fundamentals and applications. JohnWiley \& Sons, Ltd. ISBNs: 0-470-85427-8 (HB). 0-470-85428-6 (PB)

Sweety (2018) Bioremediation of Textile Dyes: Appraisal of Conventional and Biological Approaches. In: Phytobiont and Ecosystem Restitution, (Eds) Vivek Kumar, Manoj Kumar and Ram Prasad, Springer Nature Singapore pte Ltd. Singapore. 459-487 pp. doi:https://doi.org/10.1007/978-981-131187-1 23

Talwar PK, Jhingran AG (1991) Inland fishes of India and adjacent countries, vol I \& II. Oxford \& IBH, New Delhi, 1158 pp

Zimmermann T, Kulla HG, Leisinger T (1982) Properties of purified orange II azoreductase the enzyme initiating azodye degradation by Pseudomonas KF46. Eur J Biochem 129:197-203

\section{Publisher's Note}

Springer Nature remains neutral with regard to jurisdictional claims in published maps and institutional affiliations.

\section{Submit your manuscript to a SpringerOpen ${ }^{\circ}$ journal and benefit from:}

- Convenient online submission

- Rigorous peer review

- Open access: articles freely available online

- High visibility within the field

- Retaining the copyright to your article

Submit your next manuscript at $\boldsymbol{\nabla}$ springeropen.com 